\title{
Impaired ipsilateral smooth pursuit and gaze-evoked nystagmus in paramedian pontine lesion
}

Figure Recording of eye movements and radiologic findings

A
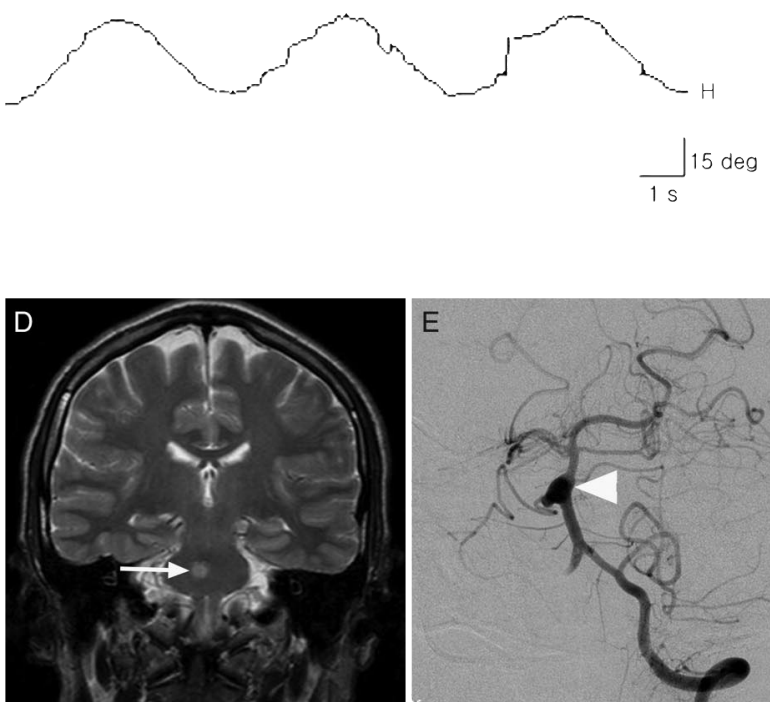

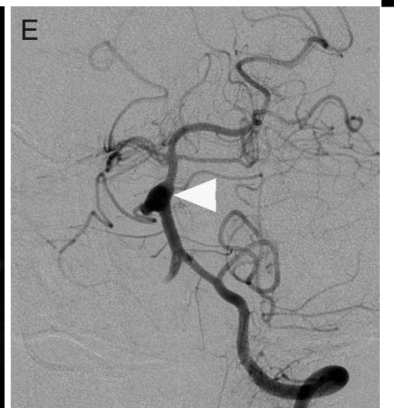

B
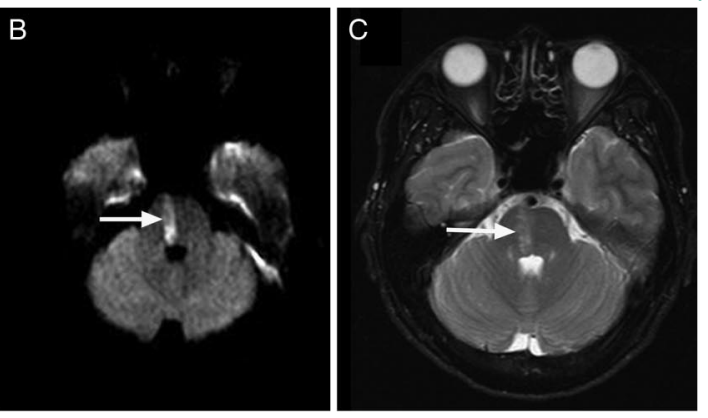

F Pontine nuclei

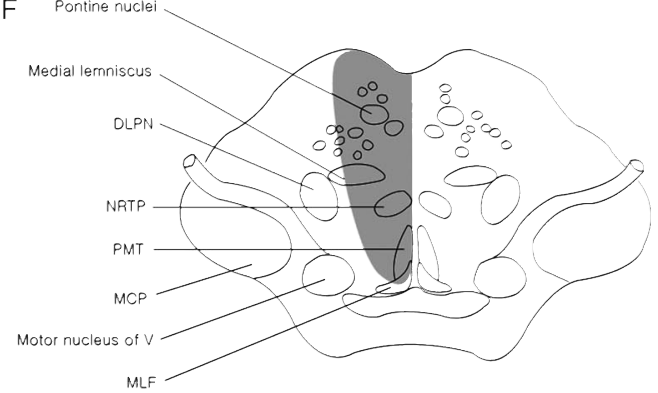

(A) During the horizontal smooth pursuit in response to a target moving sinusoidally (Micromedical, IL; $\pm 15^{\circ}$ at $0.2 \mathrm{~Hz}$ ), the rightward pursuit is interrupted by catch-up saccades while the leftward pursuit is normal. Upward deflection indicates rightward eye motion. $\mathrm{H}=$ horizontal eye position. (B through D) Diffusion-weighted axial (B) and T2-weighted axial (C) and coronal (D) MRIs show an infarction in the left paramedian middle pons (arrow). (E) Cerebral angiography reveals a dissecting aneurysm in the middle portion of the basilar artery (arrowhead). (F) Schematic diagram of the pons at the level of the motor nuclei of the trigeminal nerve. DLPN = the dorsolateral pontine nuclei; $\mathrm{MCP}=$ middle cerebellar peduncle; $\mathrm{MLF}=$ medial longitudinal fasciculus; motor nucleus of $\mathrm{V}=$ motor nucleus of the trigeminal nerve; NRTP = the nucleus reticularis tegmenti pontis; PMT = the cell group of the paramedian tracts.

VIDEO A 27-year-old man developed sudden dysarthria and left-sided weakness and paresthesia. Gaze-evoked nystagmus (GEN) was evident in bilateral horizontal gazes (see the video on the Neurology Web site at

Supplemental data at www.neurology.org www.neurology.org). Rightward pursuit was interrupted by catch-up saccades while leftward pursuit was normal (figure, A, and video). Saccadic eye movements and vestibulo-ocular reflex were normal. Brain MRI showed an infarction in the right paramedian middle pons and cerebral angiography revealed a dissecting aneurysm in the basilar artery (figure, B through E). Impaired ipsilateral smooth pursuit may result from damage to the dorsolateral pontine nuclei or nucleus reticularis tegmenti pontis while the cell group of the paramedian tracts may be a neural substrate for the generation of GEN (figure, F). ${ }^{1,2}$

B.-Y. Ahn, MD; K.-D. Choi, MD; J. Soo Kim, MD; K.-P. Park, MD; J.H. Bae, MD; and T.-H. Lee, MD,

Busan and Seoul, Korea

Disclosure: The authors report no conflicts of interest.

Address correspondence and reprint requests to Dr. Kwang-Dong Choi, Department of Neurology, College of Medicine, Pusan National University, 1-10 Ami-dong, Seo-gu, Busan, 602-739, Korea; kdchoi@medimail.co.kr

\section{REFERENCES}

1. Ono S, Das VE, Economides JR, Mustari MJ. Modeling of smooth pursuit-related, neuronal responses in the DLPN and NRTP of the rhesus macaque. J Neurophysiol 2005;93:108-116.

2. Nagamagoe K, Iwamoto Y, Yoshida K. Evidence for brainstem structures, participating in oculomotor integration. Science 2000;288:857-859. 


\section{Neurology}

\section{Impaired ipsilateral smooth pursuit and gaze-evoked nystagmus in paramedian pontine lesion}

B. -Y. Ahn, K. -D. Choi, J. Soo Kim, et al.

Neurology 2007;68;1436

DOI 10.1212/01.wnl.0000260620.65195.79

\section{This information is current as of April 23, 2007}

\section{Updated Information \&} Services

Supplementary Material

References

Permissions \& Licensing

Reprints including high resolution figures, can be found at: http://n.neurology.org/content/68/17/1436.full

Supplementary material can be found at: http://n.neurology.org/content/supp1/2007/04/19/68.17.1436.DC1

This article cites 2 articles, 1 of which you can access for free at: http://n.neurology.org/content/68/17/1436.full\#ref-list-1

Information about reproducing this article in parts (figures,tables) or in its entirety can be found online at:

http://www.neurology.org/about/about_the_journal\#permissions

Information about ordering reprints can be found online:

http://n.neurology.org/subscribers/advertise

Neurology $®$ is the official journal of the American Academy of Neurology. Published continuously since 1951, it is now a weekly with 48 issues per year. Copyright . All rights reserved. Print ISSN: 0028-3878. Online ISSN: 1526-632X.

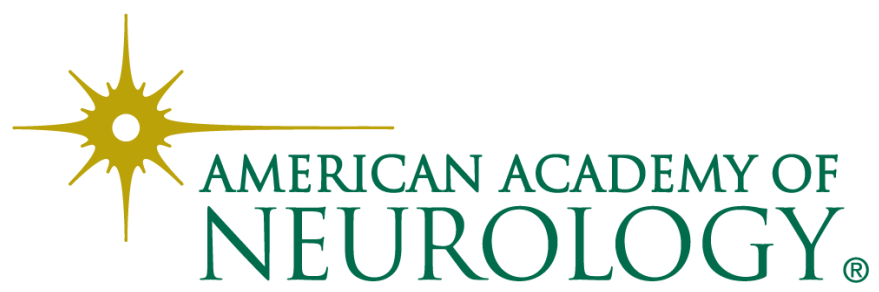

